\title{
ANALISIS PENERAPAN SISTEM INFORMASI PEMERINTAH DAERAH (SIPD) PADA BADAN PENGELOLA KEUANGAN DAN ASET DAERAH (BPKAD) KOTA MEDAN
}

\author{
Muhammad Irfan Nasution ${ }^{1}$, Nurwani ${ }^{2}$ \\ ${ }^{1,2}$ Universitas Islam Negeri Sumatera Utara
}

1.irfannasutionasril@gmail.com, $\underline{2}$ nurwani@uinsu.ac.id

\begin{abstract}
SIPD or local government Information System is an information system used in medan city government as a regional development planning system, regional financial system, as well as other local government systems, including the system of coaching and supervision of local government. However, the application of SIPD, especially in Medan, has not been carried out properly because of the quality of the system that is still lacking, in addition to the lack of efficiency in terms of time or the short time needed to conduct technical guidance causes many SKPD not yet accustomed to using SIPD. The purpose of this research is to find out how sipd implementation in Medan.. Research method used is descriptive research using qualitative approach. Based on the results of the research that has been carried out, it shows that the Medan City BPKAD has used the Regional Government Information System (SIPD) application to carry out the policies needed to carry out various activities which are programs from the Medan city government. and Based on the information obtained, the Regional Government Information System (SIPD) functions to contain the regional development planning system and regional financial system, as well as other regional government systems, including the regional government guidance and supervision system.
\end{abstract}

Keywords: Implementation, Local Government Information System.

\section{PENDAHULUAN}

Meningkatkan program pembangunan di segala bidang sebagai sarana menyampaikan informasi secara sempurna dan melibatkan semua orang secara meluas dengan memanfaatan teknologi digital menjadi harapan pengelolaan pemerintahan daerah masa kini dan masa depan (Sandiasa \& Agustana, 2017:4).

Dengan dikeluarkannya Permendagri No. 77 Tahun 2020 yang otomatis menggantikan Permendagri sebelumnya yaitu Permendagri NO. 13 Tahun 2006 tentang pedoman pengelolaan keuangan daerah. Dan seluruh SKPD Kota Medan termasuk Badan Pengelola Keuangan dan Aset Daerah (BPKAD) Kota Medan sudah tidak menggunakan aplikasi SIMDA lagi, melainkan untuk sekarang ini menggunakan aplikasi SIPD (Sistem Informasi Pemerintah Daerah) yang diatur dalam Permendagri No. 77 Tahun 2020 tentang pedoman teknis pengelolaan keuangan daerah. Anggaran memiliki fungsi sebagai alat perencanaan dan sebagai alat pengendalian. Anggaran Pendapatan dan Belanja Daerah (APBD) merupakan sumber pendanaan yang digunakan oleh pemerintah dalam menjalankan roda pemerintahan. Melalui data rekening belanja yang terdapat dalam anggaran belanja/lembaga pemerintah, akan dilihat apakah anggaran yang telah dibuat dapat berperan sebagai pengendali terhadap pelaksanaan kegiatan pemerintah. Tugas Pemerintahan daerah Mengajukan rancangan Perda, Menetapkan Perda yang sudah mendapat persetujuan dari DPRD,Mengajukan Rancangan Perda tentang APBD terhadap DPRD. Membahas rancangan Perda tentang APBD Bersama DPRD Mengupayakan terlaksananya kewajiban daerah, Mewakili daerahnya diluar atau didalam Asas Pemerintahan Daerah. Pemerintah Kota Medan Merupakan salah satu daerah yang telah menerapkan Sistem Informasi Pemerintahan Daerah (SIPD). Sistem Informasi Pemerintah Daerah (SIPD) adalah aplikasi terpadu yang dipergunakan sebagai alat bantu pemerintah daerah untuk meningkatkan efektivitas implementasi 
dari berbagai regulasi bidang pengelolaan keuangan daerah. Dalam rangka melakukan pengelolaan keuangan daerah secara transparan dan akuntabel, pemerintah memanfaatkan perkembangan teknologi yang saat ini berkembang sangat pesat, teknologi dalam bidang keuangan tersebut merupakan Sistem Informasi Pemeritah Daerah (SIPD). SIPD di Badan Pengelola Keuangan dan Aset Daerah Kota Medan masih sedang dalam tahap uji coba karena sebelumnya masih menggunakan SIMDA (Sistem Informasi Manajemen Daerah). Penerapan aplikasi berbentuk web ini bertujuan untuk meningkatkan dan memudahkan percepatan dalam pelaksanaan pengawasan dan evaluasi pelayanan publik Pemerintah Kota Medan, namun dalam menjalankan program ini tidak lah mudah harus memerlukan kerjasama dan kerja keras dari setiap instansi yang terlibat.

Kebijakan ini ditujukan untuk memberikan fasilitas dan mendorong terwujudnya sistem data dan informasi pembangunan, informasi keuangan serta informasi pemerintahan lainnya bagi pengambilan keputusan baik di daerah maupun di pusat. Sistem ini juga diharapkan dapat meningkatkan kinerja pemerintah daerah melalui kerjasama berbasis teknologi sehingga dapat membangun database yang ada di daerah serta dapat menggambarkan potensi dan sumberdaya yang dimiliki oleh daerah dalam mendukung pengembangan sistem informasi pengelolaan daerah yang valid dan akurat.

Sistem Informasi Pemerintahan Daerah atau disingkat SIPD merupakan sistem informasi yang memuat perencanaan pembangunan daerah, keuangan daerah, serta pembinaan dan pengawasan pemerintahan daerah. SIPD berfungsi juga sebagai jejaring dalam pengumpulan data secara nyata dan cepat dengan menggunakan teknologi informasi, sebagai dukungan dalam perencanaan program dan kegiatan serta evaluasi pembangunan daerah secara rasional, efektif dan efisien. Sistem ini pula dapat digunakan untuk mendukung integrase pemanfaatan data terkait dengan perkembangan pembangunan pada masing-masing instansi pemerintah. BPKAD Kota Medan sendiri mempunyai tugas melaksanakan penyusunan dan pelaksanaan kebijakan urusan pemerintahan daerah di bidang pengelolaan keuangan daerah lingkup anggaran, perbendaharaan, akuntansi dan pelaporan.

Penerapan aplikasi berbentuk web ini bertujuan untuk mempercepat dan mempermudah dalam pelaksanaan pengawasan dan evaluasi pelayanan publik pemerintah khususnya di Kota Medan, namun dalam menjalankan program ini tidak lah mudah harus memerlukan kerjasama dan kerja keras dari setiap instansi yang terlibat, berdasarkan observasi awal penulis menemukan beberapa masalah yaitu, karena pada tahun sebelumnya BPKAD Kota
Medan masih memakai SIMDA dan itu tidak ada terjadi kendala dalam pemakaiannya, akan tetapi pada awal tahun 2021 Kementerian Dalam Negeri mewajibkan seluruh OPD menggunakan aplikasi terbaru yaitu SIPD (Sistem Informasi Pemerintah Daerah) karena aplikasi tersebut masih sedang dalam tahap uji coba, maka terdapat beberapa kendala yang dihadapi oleh beberapa OPD khususnya pada BPKAD Kota Medan, dikarenakan banyaknya menu yang harus diisi dalam penginputan di SIPD seringkali para pegawai melewatkan salah satu proses penginputan sehingga laporan yang dihasilkan berbeda, pergeseran anggaran yang tertunda, sistem penggajian yang terhambat, dan juga jaringan SIPD yang sering error sehingga terjadi penghambatan dalam penyusunan anggaran kas, pembuatan SPD (Surat Penyediaan Dana), pembuatan SPJ (Surat Pertanggung jawaban), Pembuatan SPP (Surat Perintah Pembayaran), pembuatan SPM (Surat Perintah Membayar), serta pembuatan SP2D (Surat Perintah Pencairan Dana).

\section{TINJAUAN PUSTAKA Implementasi}

Di dalam buku Kebijakan Publik Teori dan Proses yang ditulis oleh Budi Winarno (2007:145) Ripley dan Frangklin dalam Bureucracy and Policy Implementation berpendapat bahwa "Implementasi adalah apa yang terjadi setelah undang-undang ditetapkan yang memberikan otoritas program, kebijakan, keuntungan (benefit), atau suatu jenis keluaran yang nyata. Istilah implementasi menunjuk pada sejumlah kegiatan yang mengikuti pernyataan maksud tentang tujuan-tujuan program dan hasil-hasil yang diinginkan oleh pejabat pemerintah. Implementasi mencangkup rangkaian tindakan (tanpa tindakan) oleh banyak aktor yang dimaksudkan untuk program berjalan."

Dalam proses kebijakan publik sebuah implementasi kebijakan merupakan tahap yang penting. Agar tujuan yang diinginkan dapat tercapai sebuah kebijakan sebagai hasil proses politis harus diterjemahkan ke dalam kegiatan nyata dan tindakan melalui proses implementasi. Setelah tahap formulasi kebijakan dilalui, Implementasi bisa disebut pernyataan kebijakan (policy statement) yang terdapat dalam sebuah kebijakan yang diputuskan akan dilaksanakan melalui berbagai langkah yang konkrit. Menurut Van Metter dan Van Horn (dalam Budi Winarno, 2007:144) "Pelaksanaan undang-undang dimana berbagai aktor, organisasi, prosedur, dan teknik bekerja bersama-sama untuk menjalankan kebijakan dalam upaya untuk meraih tujuan-tujuan kebijakan atau program-program adalah makna implementasi yang dipandang secara luas." 
Sedangkan menurut George Edward III (1980) Tahap dimana suatu kebijakan dilaksanakan secara maksimal dan dapat mencapai tujuan kebijakan itu sendiri adalah pengertian dari implementasi.

Kesimpulan dari berbagai pendapat ahli tentang konsep implementasi yaitu implementasi kebijakan merupakan suatu tahapan yang sangat penting dalam proses-proses yang berupa berbagai tindakan dari aktor-aktor untuk mencapai tujuan yang telah ditetapkan sebelumnya dengan aktivitas pencapaian tujuan sehingga mencapai hasil kegiatan.

A Model of the Policy Implementation adalah model pendekatan implementasi kebijakan yang dirumuskan Van Meter dan Van Horn (1975). Sebuah abstraksi atau performansi suatu kebijakan yang pada dasarnya secara sengaja dilakukan untuk meraih kinerja implementasi kebijakan yang tinggi yang berlangsung dalam hubungan berbagai variable adalah model proses implementasi ini. Implementasi kebijakan berjalan secara linear dari keputusan politik, pelaksana dan kinerja kebijakan publik. Model ini menjelaskan bahwa kinerja kebijakan dipengaruhi oleh variable-variabel yang saling berkaitan, secara rinci berbagai variabel tersebut yaitu:

a) Standar dan sasaran kebijakan / ukuran dan tujuan kebijakan

b) Sumber daya

c) Karakteristik organisasi pelaksana

d) Komunikasi antar organisasi

e) Disposisi atau sikap para pelaksana

f) Lingkungan sosial, politik dan ekonomi

\section{Sistem Informasi}

Kombinasi dari teknologi informasi dan aktivitas orang yang menggunakan teknologi itu untuk mendukung operasi dan manajemen adalah pengertian dari Sistem Informasi. Istilah sistem informasi dalam arti luas sering digunakan merujuk kepada interaksi antara orang, proses algoritmik, data, dan teknologi.

Tujuan dari sistem informasi adalah menghasilkan informasi. Sistem informasi adalah data yang diolah menjadi bentuk yang berguna bagi para pemakainya. Data yang diolah saja tidak cukup dapat dikatakan sebagai suatu informasi. Tepat kepada orangnya, tepat waktu, dan tepat nilai adalah tiga pilar yang harus didukung agar informasi yang dihasilkan dapat berguna. Selain yang tidak didukung oleh tiga pilar ini tidak dapat dikatakan sebagai informasi yang berguna, tetapi merupakan sampah (garbage).

Sistem informasi menurut Gordon B. Davis (1991:91) adalah suatu sistem yang menerima input atau masukan data dan instruksi, mengolah data sesuai dengan instruksi dan mengeluarkan hasilnya.

Definisi Sistem Informasi Pemerintah secara umum merupakan sebuah pengembangan dari kumpulan sistem yang terdiri dari perangkat keras dan perangkat lunak serta tenaga pelaksananya yang bekerja dalam sebuah proses berurutan dan secara bersama-sama saling mendukung mengolah data untuk menghasilkan suatu produk berupa informasi (Nataniel \& Hatta, 2009). Sementara itu Sistem Informasi Pemerintah Daerah (SIPD) memiliki pengertian sebagai Pengelolaan informasi secara sistematis berdasarkan kinerja yang sesuai dengan azas efisiensi dan efektifitas dalam mencapai tujuan organisasi diseluruh jajaran Pemerintah Daerah dalam melaksanakan pelayanan kepada masyarakat (KAUR, 2008).

\section{Sistem Informasi Pemerintahan Daerah}

Terwujudnya keterbukaan informasi publik sebagaimana diamanatkan dalam Undang-Undang Nomor 14 Tahun 2008 tentang Keterbukaan Informasi Publik yang menjamin warga negara untuk mengakses informasi publik adalah syarat minimal yang harus dipenuhi dari Sistem Informasi Pemerintah Daerah. Good Governance salah satunya adalah menyangkut "transparansi yang dibangun atas dasar kebebasan arus informasi; wajib melakukan keterbukaan informasi" (Remaja, 2017: 39). Tujuan dikelolanya SIPD adalah agar Pengelolaan Informasi Daerah secara dapat dilakukan secara professional seperti yang terdapat di dalam UU Nomor 23 Tahun 2014 bahwa Pemerintah Daerah wajib menyediakan informasi Pemerintahan Daerah (informasi pembangunan Daerah dan Informasi keuangan Daerah) dan dapat menyediakan dan mengelola informasi Pemerintahan Daerah lainnya.

Selain itu, adanya tuntutan dalam proses perencanaan pembangunan yang diamanatkan oleh Undang-Undang Nomor 25 Tahun 2004 tentang Sistem Perencanaan Pembangunan Nasional, serta keterbukaan informasi publik membuat Pemerintah terpacu untuk berinovasi dalam perencanaan pembangunan. Sehingga terbitlah Permendagri Nomor 70 Tahun 2019 Tentang Sistem Informasi Pemerintahan Daerah yang mengatur teknis pengelolaan SIPD yang sesuai dengan kebutuhan pemerintah, industri, dan masyarakat saat ini.

Penyelenggaraan Pemerintahan berbasis SPBE terpadu nasional sangat penting untuk diwujudkan menuju Good Governance dan menghasilkan satu data Indonesia yang akurat dan terintegrasi mulai daerah hingga pusat. Untuk itu, diterbitkanlah Permendagri Nomor 70 Tahun 2019 yang mengatur jenis SIPD yang dapat dikembangkan Pemerintah Daerah menjadi beberapa kelompok sebagai berikut : 
1. Informasi Pembangunan Daerah

Sistem informasi pemerintahan daerah mampu mengelola data dan informasi berkaitan dengan perencanaan pembangunan daerah dengan melibatkan berbagai elemen terkait. SIPD juga mampu dalam memfasilitasi penyusunan RPJPD, RPJMD, RKPD, RENSTRA PD, dan RENJA PD sehingga analisis dan profil dari pelaksanaan pembangunan daerah mudah diperoleh, serta mampu menjadi dasar dalam pembaharuan data dan informasi perencanaan pembangunan daerah. Kondisi geografis daerah, demografi, potensi sumber daya daerah, ekonomi dan keuangan daerah, kesejahteraan masyarakat, pelayanan umum, serta daya saing daerah adalah Informasi yang terdapat dalam perencanaan pembangunan daerah.

2. Informasi Keuangan Daerah

Sistem informasi pemerintahan daerah mampu mengelola data keuangan daerah melalui berbagai elemen terkait secara lebih efektif dan efisien dengan tetap memperhatikan asas akuntabilitas dan transparasi. Proses pengelolaan keuangan daerah yang dimaksud meliputi:

a. Perencanaan Anggaran Daerah

b. Pelaksanaan dan Penatausahaan Keuangan Daerah

c. Akuntansi dan Pelaporan Keuangan Daerah

d. Pertanggung Jawaban Pelaksanaan Keuangan Daerah

e. Pertanggung Jawaban Barang Milik Daerah

f. Informasi Keuangan Daerah lainnya

Pengelolaan data keuangan daerah menjadi sangat penting terutama dalam mencegah terjadinya praktik penyalahgunaan kewenangan khususnya keuangan daerah. Pengkodean dan pos anggaran daerah akan dipetakan secara detail dalam proses perencanaan, dan dilaksanakan secara tepat, sehingga menghasilkan pelaporan yang lebih akurat dan cepat. Pengkodean kegiatan secara nasional juga sangat membantu dalam integrasi data keuangan daerah dengan sistem informasi pemerintah pusat terutama dalam penyampaian laporan pertanggung jawaban.

3. Informasi Pemerintah Daerah Lainnya SIPD mampu memberikan informasi umum lainnya berkaitan dengan penyelenggaraan pemerintahan. Informasi umum tersebut dapat berupa Laporan Atas Penyelenggaraan Pemerintah Daerah (LPPD) selama satu tahun, PERDA, dan informasi umum lainnya yang dikelola oleh berbagai elemen terkait.

\section{METODE PENELITIAN}

Penulisan ini menggunakan penelitian kualitatif deskriptif yang dimana dengan menjelaskan data sesuai dengan hasil penelitian yang jabarkan melalui tulisan atau gambar dan bukan angka-angka sesuai dengan temuan peneliti. Menurut Bogan dan Tylor dalam buku Moleong menjelaskan bahwa penelitian kualitatif merupakan hasil dari sumber katakata tertulis yang menciptakan data deskriptif dan dapat diamati oleh peneliti sebagai permasalahan yang akan diteliti.

Informan dalam penelitian ini adalah orangorang yang dapat memberikan informasi yang akurat dan yang bertanggung jawab dalam menangani Aplikasi SIPD. Yang menjadi informan dalam penelitian ini adalah:

1. Kepala Badan Pengelola Keuangan dan Aset Daerah Kota Medan

2. Ketua Bidang Anggaran BPKAD Kota Medan

Fokus Penelitian menjadi suatu hal yang sangat penting karena fokus penelitian dapat memudahkan peneliti dalam melaksanakan penelitiannya. Dalam penelitian kualitatif hal yang harus diperhatikan adalah masalah dan fokus penelitian. Fokus memberikan batasan dalam pengumpulan data, sehingga dengan batasan ini peneliti akan fokus memahami masalah yang terjadi.

Berdasarkan pemikiran diatas maka yang menjadi fokus penelitian ini yaitu : Bagaimana Implementasi Sistem Informasi Pemerintahan Daerah di Kota Medan dengan menggunakan teori implementasi Van Meter dan Van Horn yakni :

1. Standard dan sasaran kebijakan / ukuran dan tujuan kebijakan

2. Sumber daya

3. Karakteristik organisasi pelaksana

4. Komunikasi antar organisasi 
5. Disposisi atau sikap para pelaksana

6. Lingkungan sosial, politik dan ekonomi

\section{HASIL PENELITIAN DAN PEMBAHASAN}

Perpres Nomor 95 Tahun 2018 tentang Sistem Pemerintahan Berbasis Elektronik menyebutkan bahwa penyelenggaraan pemerintahan berbasis elektronik yang memanfaatkan teknologi informasi dan komunikasi perlu diterapkan sebagai bentuk dukungan dalam rangka pengembangan pelayanan kepada masyarakat.

Tak hanya itu, terdapat amanat Perpres Nomor 54 Tahun 2018 tentang Strategi Nasional Pencegahan Korupsi yang meminta seluruh Pemda untuk mengintegrasikan antara sistem perencanaan dan sistem penganggaran pemerintah daerah dalam rangka efisiensi dan efektifitas tata kelola pemerintahan. Bahkan Perpres Nomor 39 Tahun 2019 tentang Satu Data Indonesia terdapat beberapa regulasi terkait pelaksanaan Sistem Pemerintahan Berbasis Elektronik (SPBE) yang juga baru saja diterbitkan, serta aturan kebijakan yang diterbitkan oleh Kemendagri, seperti PP Nomor 12 Tahun 2019 tentang Pengelolaan Keuangan Daerah, serta yang terakhir adalah Permendagri 70 tahun 2019 tentang SIPD ini yang memiliki tujuan yang serupa, yaitu meningkatkan pelayanan kepada masyarakat secara efektif, efisien dan akuntabel dengan memanfaatkan teknologi informasi dan komunikasi.

Sistem informasi pemerintahan daerah ini sangat bagus karena dapat memuat informasi perencanaan pembangunan daerah, informasi keuangan daerah, serta informasi yang memuat informasi pembinaan dan pengawasan pemerintahan daerah. Tujuan dari sistem ini adalah untuk menyinergikan substansi Permendagri Nomor 70 Tahun 2019 kepada Pemda Provinsi maupun Kabupaten/Kota sehingga dapat mendorong pelaksanaan pemerintahan yang lebih berkualitas, inovatif dan cepat.

Tetapi, dibalik harapan besar tentang sistem ini seperti yang dikemukakan diatas, pada kenyataannya belum ada sistem yang sempurna, masih banyak terdapat kekurangan-kekurangan pada sistem informasi pemerintahan daerah ini sehingga banyak pekerjaan dan proses penginputan lainnya mengalami keterlambatan yang sebenarnya sangat disayangkan, oleh karena itu agar berbagai masalah tersebut bisa cepat teratasi dan terwujudnya tujuan-tujuan dari sistem ini maka harus diperlukan persiapan dari setiap perangkat daerah maupun pusat baik kesiapan sumber daya manusianya harus orang-orang yang berkompeten, dan sumber daya penunjang yaitu sarana dan pra sarana karena kalau perangkat daerah dan pusat tidak sigap dan tidak bersinergi dalam menghadapi perkembangan saat ini maka kita akan ketinggalan dan sulit untuk berkembang.

Untuk mengetahui sejauh mana implementasi dari sistem informasi pemerintahan daerah (SIPD) maka peneliti menggunakan fokus penelitian sesuai teori penerapan kebijakan menurut Van Meter dan Van Horn yaitu:

1. Standard dan sasaran kebijakan / ukuran dan tujuan kebijakan

Seperti yang dikemukakan Van Meter dan Van Horn (dalam Widodo, 2007) untuk mengukur kinerja implementasi kebijakan tentunya menegaskan standar dan sasaran tertentu yang harus dicapai oleh para pelaksana kebijakan, kinerja kebijakan pada dasarnya merupakan penilaian atas tingkat ketercapaian standar dan sasaran tersebut.

Dalam hasil penelitian yang telah dilakukan menunjukan bahwa BPKAD kota medan telah menggunakan aplikasi berbasis web ini untuk melakukan kebijakan-kebijakan yang diperlukan untuk melakukan berbagai kegiatan yang menjadi program dari pemerintah kota medan. Namun, karena sistem informasi pemerintah daerah (SIPD) ini merupakan aplikasi yang masih baru, proses penerapan yang dilakukan tentu masih banyak kendala yang di dapatkan. Tapi dengan berjalannya waktu, berbagai kesalahan dan kekurangan yang ada di dalam sistem ini pasti akan diperbaiki dan akan terus di upgrade agar berbagai harapan yang mendasari dibentuknya aplikasi ini akan terpenuhi.

2. Sumber daya

Menurut Derthicks (dalam Van Mater dan Van Horn, 1975) bahwa: "New town study suggest that the limited supply of federal incentives was a major contributor to the failure of the program". Kemampuan memanfaatkan sumber daya yang tersedia adalah kunci dari keberhasilan implementasi kebijakan. Sumber daya yang terpenting dalam menentukan keberhasilan suatu implementasi kebijakan adalah manusia. Setiap tahap implementasi menuntut adanya 
peran sumber daya manusia yang berkualitas sesuai dengan pekerjaan yang diisyaratkan oleh kebijakan yang telah ditetapkan secara sistematis dan apolitis. Selain sumber daya manusia, sumber daya finansial dan waktu menjadi perhitungan penting dalam keberhasilan implementasi kebijakan.

Kemajuan suatu program salah satunya harus didukung dengan sumber daya yang memadai baik sumber daya manusia maupun sumber daya finansial, dalam hasil penelitian yang dilakukan dengan Badan pengelola keuangan dan asset daerah kota medan mendapatkan hasil bahwa sumber daya manusia telah memenuhi dan sudah sesuai dengan tupoksinya dilihat dari lapangan kebanyakan yang mengoperasikan sistem informasi pemerintahan daerah adalah yang berusia muda yang mempunyai potensi dan kemampuan dalam pengoperasian sistem informasi pemerintahan daerah, namun BPKAD Kota Medan harus lebih siap disaat terjadi pergantian kepemimpinan agar pada saat waktu penginputan data sudah dapat di input sehingga tidak terjadi keterlambatan, adapun dalam hal sumber daya sarana dan prasarana telah tersedia baik jaringan wifi, komputer dan alat penunjang lainnya sehingga badan pengelola keuangan dan asset daerah kota medan tidak kuatir lagi dalam penginputan data meskipun masih banyak kekurangan di dalam sisten informasi berbasis web ini.

3. Karakteristik organisasi pelaksana

Hal yang penting dalam pengimplentasian kebijakan adalah pusat perhatian pada agen pelaksana meliputi organisasi formal dan organisasi informal karena kinerja implementasi kebijakan akan sangat dipengaruhi oleh ciri yang tepat serta cocok dengan agen-agen selaku eksekutornya. Pelaksana kebijakan yang ketat dan displin dituntut untuk melaksanakan beberapa kebijakan. Agen pelaksana yang demokratis dan persuasive juga diperlukan dalam konteks lain. Selain itu, pertimbangan penting dalam menentukan agen pelaksana kebijakan adalah cakupan atau luas wilayah

Untuk menjalankan suatu program kegiatan maka kerjasama sangat diperlukan dalam mewujudkannya koordinasi yang jelas dan teratur pula penunjang dalam keberhasilan suatu program kegiatan, pemerintah kota Medan dalam hal ini BPKAD sebagai penanggung jawab dalam proses implementasi sistem informasi pemerintahan daerah dimana orang yang terlibat didalamnya mempunyai tugas untuk mewujudkan pembangunan agar kualitas perencanaan pembangunan daerah dan sistem keuangan daerah, serta sistem pemerintahan daerah yang lain, termasuk sistem pembinaan dan pengawasan pemerintahan daerah agar terintegrasi dengan baik.

4. Komunikasi antar organisasi

Menurut Van Horn dan Van Mater (dalam Widodo : 2007) agar kebijakan publik bisa dilaksanakan dengan efektif apa yang menjadi standar tujuan harus dipahami oleh orang yang bertanggung jawab atas pencapaian standar dan tujuan kebijakan yakni para individu (implementors), maka dari itu standar dan tujuan harus dikomunikasikan kepada para implementors. Komunikasi dalam kerangka penyampaian informasi kepada para pelaksana kebijakan tentang apa menjadi standar dan tujuan harus konsisten dan seragam (consistency and uniformity) dari berbagai sumber informasi.

Komunikasi dipakai agar hubungan antara 2 instansi atau lebih tetap berjalan dan mencapai tujuan yang disepakati bersama. Dari hasil penelitian dan pendapat dari berbagai sumber menunjukan bahwa untuk terwujudnya suatu implementasi sistem informasi pemerintahan daerah di Kota Medan salah satunya adalah kelancaran komunikasi antar kelompok pembuat kebijakan dan kelompok sasaran dalam mewujudkan informasi harus didukung oleh tiga pilar yaitu tepat kepada orangnya, tepat waktu dan tepat nilainya dan untuk tercapai semuanya itu maka diperlukan kerja sama dari setiap perangkat daerah kota Medan harus bekerja sama dalam mewujudkannya.

Sistem ini memuat sistem perencanaan pembangunan daerah dan sistem keuangan daerah, serta sistem pemerintahan daerah yang lain, termasuk sistem pembinaan dan pengawasan pemerintahan daerah. Tujuan dari sistem ini adalah untuk menyinergikan substansi Permendagri Nomor 70 Tahun 2019 kepada Pemerintah Daerah, baik di Provinsi, Kabupaten/Kota sehingga dapat mendorong penyelenggaraan pemerintahan yang lebih berkualitas, inovatif dan cepat. Namun agar terwujudnya tujuan-tujuan tersebut harus diperlukan persiapan dari setiap satuan kerja perangkat daerah baik kesiapan sumber daya manusianya harus orang-orang yang 
berkompeten, dan sumber daya penunjang yaitu sarana dan pra sarana karena kalau perangkat daerah tidak sigap dalam menghadapi perkembangan saat ini maka daerah tersebut akan ketinggalan dan sulit untuk berkembang dan pusat pun akan kesulitan dalam meningkatkan kualitas perencanaan pembangunan nasional.

Meskipun dalam penerapannya sistem ini masih banyak mengalami kendala dan itu sangat menyebabkan keterlambatan bagi proses kinerja pegawai, sistem ini menuntut pemerintah pusat untuk segera memperbaiki dan mengurangi kendalakendala yang berpotensi mendapatkan banyak kritik. Untuk itulah komunikasi sangat penting agar proses perbaikan sistem ini bisa berjalan cepat, maksimal dan suistainable.

5. Disposisi dan sikap para pelaksana

Van Metter dan Van Horn berpendapat bahwa (dalam Agostino 2006): "Pengaruh keberhasilan atau kegagalan implementasi kebijakan publik sangat bergantung dari sikap penerimaan atau penolakan dari agen pelaksana kebijakan. Hal ini sangat mungkin terjadi disebabkan karena kebijakan yang dilaksanakan bukanlah hasil formulasi warga setempat yang sangat mengenal bentuk permasalahan dan persoalan yang mereka rasakan. Tetapi kebijakan publik biasanya bersifat top down yang sangat mungkin para pengambil keputusan tidak mengetahui bahkan tak mampu menyentuh kebutuhan, keinginan atau permasalahan yang harus diselesaikan".

Keberhasilan suatu program salah satunya adalah karakter yang baik dari pelaksana kebijakan, Implementor yang memiliki sikap jujur dan komitmen dalam menjalankan suatu tanggung jawab yang di berikan maka peluang untuk kemajuan suatu pembangunan didaerah itu sangat tinggi, dalam menjalankan kebijakan yang sudah di sepakati bersama maka tidak terhindar dari berbagai masalah dan kendala dalam proses keberhasilan sebuah perencanaan pembangunan didapati dalam proses penelitian masih ada keterlambatan, hal ini menyebabkan masalah yang ada di penatausahaan, karena di penatausahaan belum siap proses $\mathrm{GU}$, TU, maupun proses pergeseran anggaran jadi terkendala karena sistemnya belum berkompeten untuk langsung diterapkan di tahun ini. Maka dari itu pemerintah pusat selaku pembuat sistem dan pembuat aturan tentang kewajiban menerapkan sistem ini harus cepat melakukan perbaikan - perbaikan agar proses kinerja yang dilakukan di setiap pemerintahan daerah tidak terkendala karena sistem yang masih banyak kekurangan.

6. Lingkungan sosial, politik dan ekonomi Sejauh mana lingkungan eksternal turut mendorong keberhasilan kebijakan publik hal terakhir yang perlu diperhatikan guna menilai kinerja implementasi kebijakan. Lingkungan sosial, ekonomi dan politik yang tidak kondusif dapat menjadi sumber masalah dari kegagalan kinerja implementasi kebijakan. Karena itu, upaya implementasi kebijakan mensyaratkan kondisi lingkungan eksternal yang kondusif.

Di dalam lingkungan BPKAD Kota Medan sendiri, kondisi sosial, politik dan ekonomi berjalan harmonis dan berkembang sebagaimana mestinya. Walaupun dalam beberapa bulan terakhir kota medan melaksanakan pemilu dan pemimpin yang berganti, itu tidak menyurutkan keharmonisan dan keseimbangan kondisi sosial, politik dan ekonomi di lingkungan Badan pengelola keuangan dan asset daerah kota medan. Hal ini tentunya sangat baik, BPKAD selaku badan yang mengurus keuangan dan asset di kota ini tentu sangat sensitif apabila terjadi ketidakharmonisan dalam proses berjalannya kegiatan, apalagi yang di kelola adalah harta milik rakyat. Namun, dengan keharmonisan yang terjadi saat initentu ini menjadi cerminan masyarakat bahwa BPKAD professional dalam menjalankan amanah mereka sebagai pelayan bagi masyarakat di Kota medan.

\section{PENUTUP}

\section{KESIMPULAN}

Berdasarkan penelitian yang telah di lakukan, maka dapat disampaikan kesimpulannya sebagai berikut:

1. Dalam hasil penelitian yang telah dilakukan menunjukan bahwa BPKAD kota medan telah menggunakan aplikasi Sistem Informasi Pemerintah Daerah (SIPD) untuk melakukan kebijakan-kebijakan yang diperlukan untuk melakukan berbagai kegiatan yang menjadi program dari 
pemerintah kota medan.

2. Berdasarkan informasi yang didapatkan Sistem informasi pemerintah daerah (SIPD) berfungsi untuk memuat sistem perencanaan pembangunan daerah dan sistem keuangan daerah, serta sistem pemerintahan daerah yang lain, termasuk sistem pembinaan dan pengawasan pemerintahan daerah.

\section{SARAN}

Untuk Badan Pengelola Keuangan dan Aset Daerah Kota Medan lebih ditingkatkan lagi kegiatan bimbingan teknis bagi setiap satuan kerja perangkat daerah yang menggunakan sistem informasi pemerintah daerah karena masih kurangnya dalam proses penggunaan aplikasi ini, dan diberikan sumber daya lebih bagi SKPD yang menangani kegiatan tersebut

Untuk peneliti selanjutnya semoga penelitian ini dapat memberikan sumbangsih dan acuan untuk penelitian-penelitian berikutnya serta menambah wawasan mengenai Sistem Informasi Pemerintah Daerah (SIPD) di BPKAD Kota Medan.

\section{DAFTAR PUSTAKA}

Agostino. (2006). Implementasi Kebijakan Publik Model Van Meter dan Van Horn, http//kertyawitaradya.wordpress, diakses 14 April 2021.

Davis, Gordon B .(1991). Kerangka Dasar Sistem Informasi Manajemen. Jakarta. PT Pustaka Binaman Pressindo.

Edward III, George C. (1980). Penerapan Kebijakan Publik. Washington DC. Husaini, Usman. 2009. Metodologi Penelitiam Sosial. Jakarta: Bumi Aksara.

KAUR, B. K. D. K. (2008). Master Plan Teknologi Informasi Pemerintah Kabupaten KAUR. In Pemerintah Kabupaten KAUR (Vol. 1).

Moleong, L.J. (2011). Metodologi Penelitian Kualitatif Edisi Revisi. Bandung: PT. Remaja Rosdakarya. OECD 2005 dalam Darmawan, 2012: 70 .

Nadya, Cita dkk, 2020. "Implementasi Sistem Pemerintahan Daerah Kota Manado (Studi di
Badan Perencanaan, Penelitian dan Pengembangan Daerah Kota Manado)". Dalam Jurnal Jurusan Ilmu Pemerintahan. Fakultas Ilmu Sosial dan Politik Universitas Sam Ratulangi.

Nataniel, D., \& Hatta, H. R. (2009). Perancangan Sistem Informasi Terpadu Pemerintah Daerah Kabupaten Paser. 4(1), 47-54.

Undang-undang No. 23 Tahun 2014 Tentang Pemerintahan Daerah

Permendagri No.77 Tahun 2020 Tentang Sistem Informasi Pemerintahan Daerah

Sandiasa, Gede dan Putu Agustana, 2017. "Reformasi Administrasi dan BirokrasiPemerintahan Daerah Dalam Menigkatkan Kualitas Layanan Publik di Daerah". Dalam Publik Inspiration Jurnal Administrasi Publik. Warmadewa. https://ejournal.warmadewa.ac.id/index.php/publi k- inspiration/article/view/824

Sudianing, Ni Ketut dan Ketut Agus Seputra, 2019. Peran Sistem Informasi Pemerintahan Daerah Dalam menunjang peningkatan kualitas perencanaan pembangunan daerah. Locus Majalah Ilmiah FISIP Vol 11.

Winarno, Budi (2007). Kebijakan Publik Teori dan Proses. Jakarta : Media Pressindo 